\title{
Biology of Diadiplosis multifila (Diptera: Cecidomyiidae) in Planococcus citri under constant temperatures
}

\author{
Alexandre Martins dos Santos ${ }^{*}$, José Eudes de Morais Oliveira², Andréa Nunes Moreira de Carvalho, \\ Martin Duarte de Oliveira², Carla Patrícia Oliveira de Assis², Fabiana Soares Cariri Lopes² \\ 'Federal Universite of Piauí, Bom Jesus, Brazilqer \\ ${ }^{2}$ Embrapa Semi-Árido, Petrolina, Brazil \\ ${ }^{3}$ Instituto Federal de Educação, Ciência e Tecnologia do Sertão Pernambucano, Petrolina, Brazil \\ *Corresponding author, email:alexandre.agro2012@hotmail.com
}

\begin{abstract}
Diadiplosis multifila was recently discovered feeding on Planococcus citri eggs in vineyards in the semi-arid northeast region of Brazil. The objective of the present paper was to study the biology of $D$. multifila in $P$. citri under constant temperatures of $22,25,28$, and $31^{\circ} \mathrm{C}$. We evaluated its embryonic stage, egg viability, development period, survival of larva and pupa, longevity, average number of eggs, and sex ratio. D. multifila completed its life cycle in all temperatures except for $31^{\circ} \mathrm{C}$. The length of the embryonic period ranged from 4 to 7 days. The larval stage was longer at a temperature of $22^{\circ} \mathrm{C}$ (8.6 days) and shorter at $28{ }^{\circ} \mathrm{C}(6.4)$. The pupal stage exhibited durations of $12.9,10.4$, and 8.2 days for temperatures of 22,25 , and $28^{\circ} \mathrm{C}$, respectively. The average viability in the larval stage was $97 \%$ and $83 \%$ in the pupal stage. The total life cycle took $16.7\left(28^{\circ} \mathrm{C}\right), 20\left(25^{\circ} \mathrm{C}\right)$, and $27\left(22^{\circ} \mathrm{C}\right)$ days to complete. The adults lived for approximately 2 days and the females produced on average 34,25 , and 19 eggs at temperatures of 22,25 , and $28^{\circ} \mathrm{C}$, respectively. The sex ratio varied from 0.46 to 0.54 .
\end{abstract}

Keywords: biological control, citrus mealybug, predator, Lower-Middle São Francisco Valley

\section{Introduction}

The Lower-Middle São Francisco Valley, home to the largest center of irrigated fruit growing in Brazil (Leão \& Moutinho, 2014), is renowned for its grape and wine production, being responsible for approximately $95 \%$ of Brazilian table grape production and $15 \%$ of its fine wine production (Zanini \& Rocha, 2010). However, in this region the grape crops have suffered production losses owing to attacks from the citrus mealybug, Planococcus citri (Risso, 1813) (Hemiptera: Pseudococcidae) (Soares \& Leão, 2009).

To control this pest, some producers apply organophosphate insecticides, which present elevated toxicity and are not selective of the pest's natural enemies (Botton et al., 2007; Arshad et al., 2015). Currently, there is a push to produce foods using fewer chemicals, with the aim to reduce impacts both human health and the environment (Zagati \& Pagliuca, 2014). For this reason, employing natural enemies for pest control is expanding in Brazil. Various natural enemies of the citrus mealybug have been recorded, including 25 parasitoid species and 33 predators such as insects and Acari (CPC, 2015).

The Cecidomyiidae family has 6,100 species (Tokuda, 2012), with only six referred to as predators (CPC, 2015). The species Diadiplosis multifila (Felt, 1907) (Diptera: Cecidomyiidae) was found in South America, the Caribbean 
and Fiji feeding on eggs of P. citri (Risso, 1813) (Hemiptera: Pseudococcidae) and Icerya montserratensis (Riley and Howard, 1890) (Hemiptera: Monophlebidae) (GAGNÉ, 1994; HARRIS, 1997).

In Brazil, D. multifila was found in the State of Espírito Santo, in the city of Vitória, feeding on different species of cochonilhas (CULIK et al., 2009). Recently, in vineyards of the Lower-Middle São Francisco Valley, the species Diadiplosis multifila (Diptera: Cecidomyiidae) was recorded in $P$. citri colonies present in grape bunches (Oliveira et al., 2013), however, little is known regarding the biology of this predator.

The present study, which investigated the biology of $D$. multifila feeding on $P$. citri eggs, contributed to the understanding of this small group of Cecidomyiidae. The literature presents information on biological parameters of the predatory species $F$. acarisuga (Gillespie et al., 2000; Mo \& Liu, 2006) and A. aphidimyza (Havelka, 1980; Kim \& Kim, 2004) which are commercialized in Europe and North America for Acari (Acari: Tetranychidae) and aphid (Hemiptera: Aphididae) control, respectively, in protected environments (Jandricic et al., 2013).

Thus, in the present study the biological data investigated for $D$. multifila was compared to these other two species of Cecidomyiidae. Thus, it is of great importance to study its bioecology, as well as the potential of $D$. multifila as an agent for $P$. citri control, with the aim to implement an applied biological control program. The present study has the objective to investigate the biology of $D$. multifila in $P$. citri under constant temperature regimes.

\section{Material and Methods}

The biological study of $D$. multifila in P. citri was conducted at the Entomology Laboratory of the Center of Agricultural Research for Semi-Arid Tropics - EMBRAPA SEMIÁRIDO, in the Petrolina municipality, Pernambuco state, Brazil. Initially, colonies of the two species involved in the present study were established, with the rearing protocols explained below.

Rearing of P. citri (Risso, 1813) (Hemiptera: Pseudococcidae)
The rearing of $P$. citri began with the collection of females in the reproductive phase from commercial vineyards in Petrolina municipality, Pernambuco state. The mealybugs were taken to the laboratory and transferred to squash (Curcubita maxima) of a variety known as "Jacarezinho." Prior to infestation, the squash were cleaned using a damp sponge and neutral detergent, rinsed in running water, and dried at ambient temperature. The infestation occurred via the transfer of approximately 500 females per squash with the aid of a flexible fine point brush.

The infested squash were maintained in plastic containers $10.5 \mathrm{~cm}$ diameter and 7 $\mathrm{cm}$ height) with perforated sides, which were placed in racks with shelves lined with paper. Approximately 30 to 50 days after infestation, the squash were replete with mealybugs at all phases of development. To increase the abundance of $P$. citri, squash without mealybugs were placed in contact with those already infested for five days. This allowed the nymphs of the first instar to move from one squash to another. The infested squash were air-conditioned at a temperature of $25 \pm 1$ ${ }^{\circ} \mathrm{C}, 70 \pm 10 \%$ relative humidity, and a photoperiod of $12 \mathrm{~h}$ light and $12 \mathrm{~h}$ dark (12L:12D).

Rearing of D. multifila (Felt, 1907) (Diptera: Cecidomyiidae)

D. multifila were obtained from collecting bunches of grapes infested with citrus mealybugs in vineyards located in Petrolina municipality, Pernambuco state. The infested plant sections were placed inside entomological cages for observation of the emergence of flies. After identifying them as D. multifila, the colony was established on $P$. citri mealybugs in Jacarezinho variety squash in wooden cages $(53.5 \times 43 \times 47.5$ $\mathrm{cm})$, with a glass top, sides of fine nylon screen, and a front covered with "voile" cloth, under controlled conditions of temperature $\left(25 \pm 1^{\circ} \mathrm{C}\right)$, relative humidity $(70 \pm 10 \%)$ and photoperiod (12L:12D). Approximately four squash infested with reproducing $P$. citri females were placed into each cage. Reproducing females are easily identified by the presence of an ovisac, which is formed by wax filaments containing eggs and is located on the lower abdomen of the mealybug. Approximately 50 male and 50 female 
D. multifila were released into each cage to potentially couple and take their appropriate positions. The sex classification was determined by observing the ovipositor apparatus. After hatching, D. multifila larvae fed on P. citri eggs until the pupal stage. After the emergence of $D$. multifila adults, new squash infested with $P$. citri females in the reproduction phase were placed in the cage to ensure an adequate food supply for the new generation.

Biology of D. multifila at different temperatures The biological aspects of D. multifila were studied under constant temperatures of $22,25,28$, and $31{ }^{\circ} \mathrm{C}$, relative humidity of $60 \pm$ $10 \%$, and photoperiod of 12L: 12D. Initially, ten mealybugs with ovisacs from the reared stock were placed inside plastic containers $18.5 \mathrm{~cm}$ diameter and $5.5 \mathrm{~cm}$ height) with the bottom lined with filter paper. This density of mealybugs in the container was determined using results from previous experiments evaluating the oviposition of D. multifila in different densities of D. multifila. Following this, five females and five males adults of $D$. multifila were transferred from the reared stock to the plastic container using an entomological vacuum apparatus. This procedure was performed to obtain mating and oviposition. After this transfer, the container was sealed with plastic film and the adults were confined for $24 \mathrm{~h}$.

After the D. multifila larvae hatched, which lasted in half five days, two each individual (up to $3 \mathrm{~h}$ old) was transferred with the aid of a fine pointed craft knife to a Petri dish $15 \mathrm{~cm}$ diameter), which contained ten ovisacs full of eggs, randomly selected from the rearing of $P$. citri, that were the food source. Soon after, the dishes were sealed with plastic film and placed in air-conditioned chambers. Every day, D. multifila larvae were offered mealybug eggs (average of 50 eggs) collected from the rearing stock to ensure food ad libitum. After emergence, a D. multifila female was transferred and released again into the plastic container holding ten mealybugs with ovisacs, droplets of $P$. citri honeydew was offered as food, and five D. multifila males from the rearing stock were made available for coupling and later oviposition.
Biological aspects were evaluated for each temperature in at least 50 individuals, with each one of these corresponding to one replication. The following factors were then evaluated: the embryonic period, egg viability, development period and survival of larva and pupa, as well as longevity, average number of eggs, and sex ratio.

\section{Statistical Analyses}

The egg-adult period of D. multifila observed at the different temperature ranges, was employed to determine the lower threshold temperature (LTT) or base temperature (T-base) and the thermal constant (K) in degree-days (DD). The hyperbole method (Haddad et al., 1999) was used through the SAS version 2.8 program (SAS Institute, 2001). The results were then subjected to analysis of variance (ANOVA) following a randomized experimental design with four treatments (temperatures) and 50 replications. When significant differences from the ANOVA occurred, the averages of the treatments were subjected to Tukey's HSD test to $5 \%$ probability for averages comparison.

\section{Results and Discussion}

The development periods (days) embryonic period, the larval and pupal stages, and the total life cycle (egg to adult period) of D. multifila, fed from P. citri, decreased as temperature increased (Table 1). When subjected to a temperature of $31^{\circ} \mathrm{C}$, all $\mathrm{D}$. multifila individuals died at three days of age, high temperatures have been a limiting factor for the predators of the Cecidomyiidae family (Kim \& Kim, 2004).

At $22^{\circ} \mathrm{C}$, the development periods were 7.0, 8.6, 12.9 and 26.9 days for the embryonic period, larval and pupal stages, and total life cycle (egg to adult) periods, respectively. Here were significant differences $(P<0.05)$ in the temperature ranges, from $28^{\circ} \mathrm{C}$ to $22^{\circ} \mathrm{C}$ for all periods of development (Table 1). Mo \& Liu (2006) observed that at a temperature of $26.7^{\circ} \mathrm{C}$ and relative humidity of $75 \%$, the embryonic phase of $F$. acarisuga lasted for 2.6 days, on average. Gillespie et al. (2000) found that at temperatures of 20,27 , and $30^{\circ} \mathrm{C}$, the embryonic period of $F$. 
acarisuga was on average 1.7, 1.5, and 2.2 days, respectively.

The length of the larval stage of D. multifila showed significant differences between the temperatures (Table 1). At $28^{\circ} \mathrm{C}$, the larval stage was shorter ( 6.4 days), while at $22^{\circ} \mathrm{C}$ the larval stage was the longest ( 8.6 days). The larval stage lasted for 7.6 days on average with a range of 6 to 8 days. Gillespie et al. (2000) established that
F. acarisuga feeding on Tetranychus urticae eggs at 20 and $30^{\circ} \mathrm{C}$ showed a larval stage of 12.9 and 7.9 days, respectively. Mo \& Liu (2006) observed that, when $F$. acarisuga fed on $T$. cinnabarinus eggs, the larval stage lasted approximately seven days at a temperature of $26^{\circ} \mathrm{C}$. The larval stage of these species of Cecidomyiidae predators varies from 5 to 12 days, at temperatures between 20 and $30^{\circ} \mathrm{C}$ (Kim \& Kim, 2004; Havelka, 1980).

Table 1. Length (days) of the embryonic, larval and pupal stages, and total life cycle (egg to adult) of Diadiplosis multifila reared in Planococcus citri at temperatures of 22,25 , and $28^{\circ} \mathrm{C}$ at the Embrapa Semiarid Entomological Laboratory, Petrolina, Pernambuco state

\begin{tabular}{lllll}
\hline \multirow{2}{*}{ Temp. ( $\left.{ }^{\circ} \mathrm{C}\right)$} & \multicolumn{4}{l}{ Length (average $\pm \mathrm{SE}$ ) of the stages } \\
& EEmbryo & Larva & Pupa & Egg-adult \\
$\mathbf{2 2}$ & $7.0 \pm 0.02 \mathrm{a}$ & $8.6 \pm 0.11 \mathrm{a}$ & $12.9 \pm 0.15 \mathrm{a}$ & $26.9 \pm 0.15 \mathrm{a}$ \\
$\mathbf{2 5}$ & $5.0 \pm 0.02 \mathrm{~b}$ & $8.0 \pm 0.16 \mathrm{~b}$ & $10.4 \pm 0.50 \mathrm{~b}$ & $20.0 \pm 0.24 \mathrm{~b}$ \\
$\mathbf{2 8}$ & $4.0 \pm 0.02 \mathrm{C}$ & $6.4 \pm 0.09 \mathrm{C}$ & $8.2 \pm 0.24 \mathrm{C}$ & $16.7 \pm 0.20 \mathrm{C}$ \\
\hline Averages $( \pm$ SE) followed by the same letter in the column do not differ between themselves using the Tukey's HSD test at 5\% probability.
\end{tabular}

The pupal stage of D. multifila was also influenced by the temperatures (Table 1), presenting significantly different durations of 12.9 , 10.4, and 8.2 days for temperatures of 22,25 , and $28^{\circ} \mathrm{C}$, respectively (Table 1). On average, the pupal stage was 10.5 days, with a range of 8 to 13 days. Gillespie et al. (2000) observed that the pupal stage of $F$. acarisuga at temperatures of 20,27 , and $30{ }^{\circ} \mathrm{C}$ was $7.5,4.9$, and 4.9 days, respectively. Mo \& Liu (2006) showed that the pupal stage of $F$. acarisuga lasted, on average, 6.7 days at a temperature of $26^{\circ} \mathrm{C}$.

Havelka (1980) observed that at temperatures of 15,20 , and $25^{\circ} \mathrm{C}$ and relative humidity of $80-100 \%$ the embryonic period of A. aphidimyza lasted on average 1.8, 2.6, and 5 days, respectively and pupal stage of $A$. aphidimyza at 20 and $25^{\circ} \mathrm{C}$ was 10.9 and 7.9 days, respectively. Thus, the embryonic period of D. multifila corresponds, on average, to double the number of days of $F$. acarisuga and $A$. aphidimyza at approximately $25^{\circ} \mathrm{C}$.

The length of the total life cycle (egg to adult) of D. multifila diminished significantly with an increase in temperature, presenting the highest development period at $22^{\circ} \mathrm{C}$ (27 days) and the lowest at $28^{\circ} \mathrm{C}$ (17 days) (Table 1). These results are in agreement with those obtained by Gillespie et al. (2000) and Havelka (1980), who observed that the total life cycle length of $F$. acarisuga and $A$. aphidimyza, respectively, was inversely proportional to the increase in temperature. $F$. acarisuga completed its development between 20 and 16 days at temperatures of 20 to $30^{\circ} \mathrm{C}$ (Gillespie et al., 2000), whereas the total life cycle length of $A$. aphidimyza was 28 and 16 days at 20 and $30^{\circ} \mathrm{C}$, respectively. Thus, the total life cycle length of $D$. multifila is similar to that of the species A. aphidimyza.

The viability of $D$. multifila eggs at the three temperatures $\left(22,25\right.$, and $\left.28^{\circ} \mathrm{C}\right)$ was high, corresponding to $99 \%$. The pupal stage viability of D. multifila was $83 \%$ on average, being less than the larval viability (Table 2). Diadiplosis multifila have three larval instars, observed by the skin casting process, which is typical of members of the family Cecidomyiidae. However, the duration of each instar was not measured because after hatching the larvae moved into the ovisac, where generally they were found covered by the mealybug eggs.

To observe the change at each instar, it was necessary to take out the larvae from the inside of the ovisac. In performing this daily procedure, there was a high degree of mortality of the individuals. Therefore, it was only possible to determine the larval period, as during this phase manipulation was less frequent. Madahi et al. (2013), studying the predation efficiency of A. aphidimyza, were also not able to differentiate the instars and conducted their experiment using the specific age of the larvae instead. 
Table 2. Viability (\%) of egg, larva* and pupal stages of Diadiplosis multifila reared in Planococcus citri at temperatures of 22,25 , and $28^{\circ} \mathrm{C}$ at the Embrapa Semiarid Entomological Laboratory, Petrolina, Pernambuco state

\begin{tabular}{|c|c|c|c|c|c|c|}
\hline \multirow{3}{*}{$\begin{array}{l}\text { Viability } \\
\text { Parameter }\end{array}$} & \multicolumn{6}{|c|}{ Temperature $\left({ }^{\circ} \mathrm{C}\right)$} \\
\hline & \multicolumn{2}{|c|}{22} & \multicolumn{2}{|c|}{25} & \multicolumn{2}{|c|}{28} \\
\hline & $\%$ & $\mathbf{N}$ & $\%$ & $\mathbf{N}$ & $\%$ & $\mathbf{N}$ \\
\hline Egg & 99 & 600 & 99 & 600 & 99 & 600 \\
\hline \multicolumn{7}{|l|}{ Larva* } \\
\hline 1 day & 100 & 69 & 100 & 150 & 100 & 171 \\
\hline 2 days & 91.3 & 63 & 100 & 150 & 91.2 & 156 \\
\hline 3 days & 92.0 & 58 & 97.3 & 146 & 98.4 & 154 \\
\hline 4 days & 100 & 58 & 100 & 146 & 91.2 & 143 \\
\hline 5 days & 100 & 58 & 99.3 & 145 & 97.5 & 140 \\
\hline 6 days & 91.3 & 53 & 100 & 114 & 100 & 113 \\
\hline 7 days & 100 & 40 & 100 & 82 & - & - \\
\hline 8 days & 100 & 39 & 100 & 59 & - & - \\
\hline Larval stage & 97.5 & 69 & 96.9 & 150 & 96.3 & 171 \\
\hline Pupal stage & 88.0 & 42 & 76.7 & 112 & 84.9 & 133 \\
\hline
\end{tabular}

From the first day of life to the last before becoming a pupa, larval survival was high at all temperatures, varying from 91 to $100 \%$ (Table 2). Average larval viability of D. multifila was $97 \%$. At the completion of the juvenile phase, the larvae suspended movement and feeding. Instead, they started secreting a silky substance around their bodies, which formed a cocoon and is where they remained until emergence.

Kim \& Kim (2004) observed that the pupal stage of $A$. aphidimyza at temperatures of 20,25 , and $30^{\circ} \mathrm{C}$ lasted on average 17.5, 8.4, and 9.7 days, respectively. Thus, the pupal stage of D. multifila, F. acarisuga, and A. aphidimyza varies from 5 to 17 days between 20 and $30{ }^{\circ} \mathrm{C}$. The lowest pupal viability was observed at a temperature of $25^{\circ} \mathrm{C}(76 \%)$ and the highest was at $22{ }^{\circ} \mathrm{C}(88 \%)$.

The longevity of adult male and female $D$. multifila varied with temperature. At temperatures of 22 and $25^{\circ} \mathrm{C}$, the longevity of the male was similar (approximately 2.5 days) and significantly greater than at $28{ }^{\circ} \mathrm{C}$ where longevity was one day shorter ( 1.5 days) (Table 3 ). The adult male of $F$. acarisuga lives, on average, for 12 days at a temperature of $26.7^{\circ} \mathrm{C}$ (Mo \& Liu, 2006), a longevity much greater than that seen in D. multifila.

The female longevity of $D$. multifila showed values significantly greater at $22^{\circ} \mathrm{C}$ than at $28^{\circ} \mathrm{C}$, having averages of 2.2 and 1.5 days, respectively (Table 3 ).

Table 3. Longevity (days; average $\pm \mathrm{SE}$ ), fertility, and sex ratio of Diadiplosis multifila reared in Planococcus citri at temperatures of 22,25 , and $28^{\circ} \mathrm{C}$ at the Embrapa Semiarid Entomological Laboratory, Petrolina, Pernambuco state

\begin{tabular}{|c|c|c|c|c|c|c|c|}
\hline \multicolumn{8}{|c|}{ Temperature $\left({ }^{\circ} \mathrm{C}\right)$} \\
\hline \multirow[t]{2}{*}{ Parameter } & \multicolumn{2}{|c|}{22} & \multicolumn{2}{|l|}{25} & \multicolumn{2}{|c|}{28} & \multirow[t]{2}{*}{$F^{p}$} \\
\hline & Average & $\mathbf{N}$ & Average & $\mathbf{N}$ & Average & $\mathbf{N}$ & \\
\hline Long. $\widehat{o}$ & $2.52 \pm 0.17 a$ & 17 & $2.41 \pm 0.19 a$ & 17 & $1.47 \pm 0.15 b$ & 17 & $11.18^{0.001}$ \\
\hline Long. $q$ & $2.20 \pm 0.20 a$ & 20 & $2.15 \pm 0.18 \mathrm{ab}$ & 20 & $1.55 \pm 0.15 b$ & 20 & $4.06^{0.024}$ \\
\hline Eggs/q & $34.23 \pm 3.62 a$ & 17 & $25.40 \pm 3.12 \mathrm{ab}$ & 25 & $19.58 \pm 2.47 b$ & 29 & $5.44^{0.0064}$ \\
\hline Sex ratio & 0.54 & 37 & 0.50 & 86 & 0.46 & 113 & - \\
\hline
\end{tabular}

Gillespie et al. (2000) showed that the longevity of the female F. acarisuga varied from 4.6 to 5.6 days between temperatures of 20 and $25^{\circ} \mathrm{C}$. Kim \& Kim (2004) discovered that A. aphidimyza females survived for approximately 5.0 to 6.8 days at a temperature of $25{ }^{\circ} \mathrm{C}$. Therefore, D. multifila adults are ephemeral and present lesser longevity than other Cecidomyiidae predator species. In general, as D. multifila adults survive for only two days, the coupling must occur soon after emergence and as soon as the females perform oviposition. The D. multifila females confined with males in conta iners with mealybugs in reproduction phase, 
deposited their eggs on or inside the ovisacs and on the white filter paper, which was used to line the bottom of the container.

In evaluating the fertility of D. multifila, it was shown that the females produced significantly more eggs when they developed at 22 and $25^{\circ} \mathrm{C}$. Thus, the fertility of $\mathrm{D}$. multifila varied from 34 to 19 eggs, respectively, and displayed a reduction in egg production with increase in temperature (Table 3). Gillespie et al. (2000) indicated that $F$. acarisuga produced, on average, 42 eggs at 20 and $25^{\circ} \mathrm{C}$, and that the temperature did not affect fertility. Mo \& Liu (2006) showed that $F$. acarisuga deposited on average 32.4 eggs during its cycle at $26.7^{\circ} \mathrm{C}$. These results show that the species D. multifila and $F$. acarisuga have similar fertility, with each female able to deposit between 20 and 45 eggs.

The individuals that hatched on or inside the ovisac quickly found the eggs and fed on them until the pupal stage. In contrast, the larvae that hatched on the filter paper moved around the container, were unable to locate the ovisac, and died after one day of life owing to lack of food. Thus, the selection of the place of oviposition is revealed as a determining factor in the survival of $D$. multifila larvae.

The sex ratio of $D$. multifila varied from 0.46 to 0.54 (Table 3 ). It occurred a reduction in the number of $D$. multifila females with an increase in temperature. In terms of the sex ratio of other Cecidomyiidae, $F$. acarisuga showed a female rate of $60 \%$ at $26.7^{\circ} \mathrm{C}$ (Mo \& Liu, 2006), while A. aphidimyza revealed a rate of $45 \%$ at 22 ${ }^{\circ} \mathrm{C}$ (Van Lenteren, 2003). Therefore, the D. multifila sex ratio is slightly lower than that of $F$. acarisuga and comparable to that of A. aphidimsyza under similar temperature conditions.

D. multifila develop in temperatures between 22 and $28{ }^{\circ} \mathrm{C}$. This Cecidomyiidae species was discovered in grape bunches infested with $P$. citri collected in vineyards in the Petrolina municipality, Pernambuco state (Oliveira et al., 2013), which is located in a semiarid region where the average annual temperature has variations from 20.7 to $26.8{ }^{\circ} \mathrm{C}$ (Ramos et al., 2011). Thus, D. multifila are adapted to develop in these temperature conditions of the semiarid northeast of Brazil. One of the characteristics of this region is the presence of two climatic seasons: wet and dry. In the latter, from August to October, the temperature can reach peaks equal to or greater than $31^{\circ} \mathrm{C}$ (Santos et al., 2013).

D. multifila do not complete their development cycle at $31^{\circ} \mathrm{C}$. Therefore, how can we explain the survival of $D$. multifila in the semiarid region during periods of high temperatures? In nature, climatic conditions are quite different, as during the day there are variations in temperature. Therefore, D. multifila may present behavioral adaptations, which allow its survival when there is a wide temperature range. For example, D. multifila adults may seek refuge in a section of the grape vine and/or oviposition sites that have a microclimate with a more amenable temperature, such as shaded branches or grape clusters.

D. multifila present several biological similarities with the Cecidomyiidae species $F$. acarisuga and A. aphidimyza, which are reared en masse and commercialized. However, the species D. multifila warrants attention, requiring further studies to evaluate its potential as a predator, with a view to the implementation of a program of applied biological control.

\section{Conclusions}

Temperatures of 22,25 and $28^{\circ} \mathrm{C}$ favored the development of all phases of $D$. multifila. At $31^{\circ} \mathrm{C}$, there was a high mortality of insects, especially in the larva stage.

It was evidenced that the constant temperatures of $25^{\circ} \mathrm{C}$ and $28^{\circ} \mathrm{C}$, provide a reduction of the biological cycle of $D$. multifila, but presented a lower fecundity, in relation to $22^{\circ} \mathrm{C}$.

D. multifila presented biological similarities in relation to the species of Cecidomyiidae, F. acarisuga and A. aphidimyzia. In this way D. multifila deserves attention, and further studies are needed to evaluate its predation potential aiming at the implementation of an applied biological control program.

\section{Acknowledgments}

To CAPES for the study grant given to Alexandre Martins dos Santos. For the financial support of FACEPE/CNPq through the project APQ-0408-5.01/13. To the Federal University of Piauí and to Embrapa Semiárido for the logistical 
and structural support necessary for the research.

\section{References}

Arshad, M., Majeed, M.Z., Ullah, M.I., Ahmad, K., Tayyab, M., Yahya, M. 2015. Laboratory evaluation of some insecticides against citrus mealybug Planococcus citri, (Homoptera: Pseudococcidae). Journal of Entomology and Zoology Studies 3: 20-23.

Botton, M., Fajardo, T.V.M., Morandi Filho, W.J., Grutzmacher, A.D., Prado, E. 2007. Vetor encoberto - cochonilhas algodonosas em uva. Cultivar Hortaliças e Frutas 7: 28-29.

Cichon, L., Garrido, S., Ferandez, D. 2009. Cochinilla harinosa: cómo prepararse para su reconocimiento, monitoreo y control durante la próxima temporada. Fruticultura \& Diversificacion 60: 24-31.

CPC. Crop Protection Compendium. 2015. http:// www.cabi.org/cpc/<Acesso em 20 Dez. 2015>

Gillespie, D.R., Opit, G., Roitberg, B. 2000. Effects of temperature and relative humidity on development, reproduction and predation in Feltiella acarisuga (Vallot) (Diptera: Cecidomyiidae). Biological Control 17: 132-138.

Havelka, J. 1980. Affect of temperature on the developmental rate of preimaginal stages of Aphidoletes aphidimyza (Diptera, Cecidomyiidae). Entomologia Experimentalis et Applicata 27: 83-90.

Jandricic, S.E., Wraight, S.P., Gillespie, D.R., Sanderson, J.P. 2013. Oviposition behavior of the biological control agent Aphidoletes aphidimyza (Diptera: Cecidomyiidae) in environments with multiple pest aphid species (Hemiptera: Aphididae). Biological Control 65: 235-245.

Kim, T.H., Kim, J.S. 2004. Development and adult life span of Aphidoletes aphidimyza (Rondani) (Diptera: Cecidomyiidae) fed on the melon aphid, Aphis gossypii Glover of the green peach aphid, Myzus persicae (Sulzer) (Hemiptera: Aphididae). Korean Journal of Applied Entomology 43: 297304.

Leão, E.L.S., Moutinho, L.M.G. 2014. O arranjo produtivo local de fruticultura irrigada do Vale do Submédio do São Francisco como objeto de política. Race 13: 829-858.

Madahi, K.H., Sahragard, A., Hossieni, R. 2013. Larval age-specific searching efficiency of Aphidoletes aphidimyza (Diptera: Cecidomyiidae) preying on different densities of Aphis craccivora (Hemiptera: Aphididae). Journal of Entomological Society of Iran 33: 33-43.

Mo, T.L., Liu, T.X. 2006. Biology, life table and predation of Feltiella acarisuga (Diptera: Cecidomyiidae) feeding on Tetranychus cinnabarinus eggs (Acari: Tetranychidae). Biological Control 39: 418-426.

Morandi Filho, W.J., Grutzmacher, A.D., Botton, M., Bertin, A. 2009. Controle químico da cochonilha-farinhenta Planococcus citri (Risso, 1813) (Hemiptera: Pseudococcidae) em diferentes idades da videira. Arquivos do Instituto Biológico 76: 427-435.

Oliveira, J.E. de M., Fernandes, M.H.A., Silva, J.G., Paz, H.H.R., Menezes, K.O., Maia, V.C. 2013. Ocorrência de Diadiplosis multifila (Diptera: Cecidomyiidae) associada à Planococcus citri (Hemiptera: Pseudococcidae) em videira no Semiárido Brasileiro. in: Simpósio de controle biológico, 13, 2013, Bonito. Faça bonito: use controle biológico. Anais. Brasília, DF: Embrapa.

Ramos, C.M.C., Silva, A.F. da., Sartori, A.A. da. C., Zimback, C.R.L., Bassoi, L.H. 2011. Modelagem da variação horária da temperatura do ar em Petrolina, PE, e Botucatu, SP. Revista Brasileira de Engenharia Agrícola e Ambiental 15: 959-965.

Sanches, N.F., Carvalho, R.S. 2011 . Multiplicação do predador exótico Cryptolaemus montrouzieri como alternativa de controle biológico clássico para o controle da cochonilha exótica Maconellicoccus hirsutus. Cadernos de Agroecologia 6: 1-5.

Santos, A.E.O. dos., Silva, E. de O., Oster, A.H., Mistura, C., Santos, M.O. dos. 2013. Resposta fenológica e exigência térmica de uvas apirenas cultivadas no Submédio do São Francisco. Revista Brasileira de Ciências Agrárias 8: 364-369.

Tokuda, M. 2012. Biology of Asphondyliini (Diptera: Cecidomyiidae). Entomological Science 15: 361383.

Soares, J.M., Leão, P.C. de S. 2009. A Vitivinicultura no Semiárido Brasileiro. Embrapa Informação Tecnológica, Petrolina, BRA. 756p.

Van Lenteren, J.C. 2003. Commercial availability of biological control agents. In: Van Lenteren, J.C. (ed.) Quality control and production of biological control agents: theory and testing procedures. Wallingford. Inglaterra. p. 167-179.

Zagati, F., Pagliuca, L. 2014. Agentes do Bem: Biológicos entram em ação! O mercado de produtos biológicos é promissor. Revista Hortifruti Brasil 136: 10-18.

Zanini, T.V., Rocha, J.M. 2010. O Enoturismo no Brasil: um estudo comparativo entre as regiões vinícolas do Vale dos Vinhedos (RS) e do Vale do São Francisco (BA/PE). Revista Turismo em Análise 21: 68-88. 